\title{
The English School and Global IR - A Research Agenda
}

\author{
Filippo Costa Buranelli \\ University of St Andrews
}

Simon F. Taeuber

University of St Andrews

\begin{abstract}
This paper explores the different ways in which the English School of International Relations (ES) can contribute to the broader Global IR research agenda. After identifying some of the shared concerns between the ES and Global IR, such as the emphasis placed on history and culture, the paper proceeds with discussing what the authors believe to be the areas in which the ES can align itself more closely with the ideas and values underpinning Global IR: a more thorough engagement with the origins of global international society rooted in dispossession, violence, and colonialism; a more localised and diverse understanding of 'society'; a sharper and more grounded conceptualisation of 'the state' as a basic ontology; an embracement of the interpretivist principle of charity; and a problematisation of assumptions of 'globality' of international society. The paper concludes with a tentative research agenda, emphasising the value of fieldwork, local practices and languages, archives, and a theorisation of international society that is grounded in the very social contexts being investigated.
\end{abstract}

Keywords: English School, Global IR, Eurocentrism, locality, grounded theory

\section{Introduction - The English School and Global IR}

In recent times, International Relations (henceforth IR) as a discipline has been undergoing a series of transformations both in the topic of the inquiry (what is studied, and how) and in the professional structure that informs it (who studies what). This is observable, for example, in the progressive expansion of scholarship on race and decoloniality, as well as in the sustained calls for inclusion of contributions, voices, and perspectives from the Global South with the objective of truly globalising IR. In fact, recognition of the need for globalising IR has far deeper roots 'in the lineage anticipated by Hoffmann 1977, Bull 1985, Cox 1981, Alker 1984, Holsti 1985, Ashley 1987 and it is now taken up by scholars from both the Global North and the Global South who use different terms like "worlding". ${ }^{1}$ The 'international' has progressively made room for 'the global', meant as the totality of actors, voices, perspectives,

Filippo Costa Buranelli, School of International Relations, University of St Andrews, Scotland. Email: fcb7@st-andrews.ac.uk 0000-0002-2447-7618.

Simon F. Taeuber, School of International Relations, University of St Andrews, Scotland. Email: sft1@st-andrews.ac.uk 0000-0003-0740-3366.

Petition to ISA, September 2020, accessed December 3, 2020, https://smsjm.vse.cz/english/wp-content/uploads/sites/2/ post/250/Petition-to-ISA-GG.pdf. 
and experiences that constitute world politics in its multiplicity and diversity: states, nations, refugees, displaced people, civil movements, guerrillas, women, indigenous people, queers, religious movements, animals, and many more. ${ }^{2}$ This expansion has been accompanied by debates on 'subjugated knowledges' pertaining to how ontologies, epistemologies, and methodologies that are not necessarily rooted in the Global North (nor in Western political thought and philosophy) can take their rightful place next to what have so far been considered canonical, established bodies of thought and traditions through a process of epistemological decolonisation. ${ }^{3}$

Crucially, these debates have been advanced by several scholars, professionals, and analysts from the Global South who are now, at last, having a more prominent voice within international, yet still profoundly Western-dominated, professional institutions. As a small, and by all means not exhaustive example of this, not only has the International Studies Association (ISA) started including abstracts in languages other than English, such as Spanish and French, in some of their journals (e.g. International Studies Review, outside the ISA circuit see e.g. Millennium: Journal of International Studies among others), but also a new fully open-access journal, Global Studies Quarterly, has been founded with the aim of being 'open to all methodological approaches to questions of international politics, or the intersection of global politics with economy, society, or culture' and to 'encourage submissions from scholars and regions that are often underrepresented in academic journals'. ${ }^{4}$ These debates have focused on the need and the desirability of 'decentring' or even 'provincializing' IR 5 from both 'the state' and 'the West' as an uncontested site of knowledge generation and dissemination, encouraging and indeed promoting a plurality of voices and perspectives that have thus far been 'subaltern' to the mainstream discipline.

What is at stake here, though, is more than pluralism. It is a broader normative understanding of epistemic justice based on inclusivity, respect, openness, and attention to the contributions coming from 'the periphery' (again, geographical, i.e., from the Global South, but most importantly disciplinary, here understood as being at the fringes, disregarded by big journal outlets, unlikely to be funded, and similar experiences) - it is a fundamental discussion about whose knowledge (also) counts and is recognised. As part of the process of further institutionalisation, some ISA members have launched the initiative to create a new section named 'Global IR' within the organisation.

But what, exactly, is 'Global IR'? In this paper, we take a very broad approach to Global IR, considering it in all its facets: a research programme, an agenda, a social (academic) movement, a normative ideal, an initiative, and an 'aspiration for greater inclusiveness and diversity' with an open and non-prescriptive character. It has its roots in non-Western, postWestern, post-colonial scholarships, and rests on six main features. ${ }^{6}$ First, Global IR advances the idea of a pluralistic universalism, that IR theory should not be based on a one-size-fitsall approach to international politics but should rather embrace different perspectives and

2 James Tully, Strange Multiplicity: Constitutionalism in an Age of Diversity, The Seeley Lectures (Cambridge: Cambridge University Press, 1995).

Ananya Sharma, "Decolonizing International Relations: Confronting Erasures through Indigenous Knowledge Systems," International Studies 58, no. 1 (2021): 25-40; Karen Tucker, "Unraveling Coloniality in International Relations: Knowledge, Relationality, and Strategies for Engagement," International Political Sociology 12, no. 3 (2018): 215-32.

4 "Global Studies Quarterly - About", accessed December 4, 2020, https://academic.oup.com/isagsq/pages/About.

Dipesh Chakrabarty, Provincializing Europe (Princeton University Press, 2007).

6 Amitav Acharya, "Global International Relations (IR) and Regional Worlds: A New Agenda for International Studies," International Studies Quarterly 58, no. 4 (2014): 647-59. 
display awareness of its multiple historical and social foundations. Second, it promotes the endeavour to derive concepts and theories from the specific historical experiences, ideas, institutions, and intellectual perspectives of Western and non-Western societies alike. This is in line with Chakrabarty's point that 'Western analytical and theoretical categories remain indispensable but inadequate'. ${ }^{7}$ Third and following from this, Global IR seeks to subsume existing theories within a framework of plurality and equality, as opposed to rejecting them. Fourth, it emphasises the role of regions as sites of global dynamics. ${ }^{8}$ Fifth and linked to the previous point is the idea that researchers should transcend 'eschewing cultural exceptionalism and parochialism by favouring comparative perspectives and the search for broader understandings of local contexts'. ${ }^{9}$ Sixth and finally, Global IR embraces a broad understanding of 'actors' and 'agency', stressing the importance of both statist and nonstatist ontologies, and of 'how actors (state and non-state), through their material, ideational, and interaction capabilities, construct, reject, reconstitute, and transform global and regional orders'. ${ }^{10}$

Against this background, one may ask what the position of the English School (ES) is, with ES meant both as a body of intellectual and scholarly research as well as a community of scholars. Amitav Acharya, one of the most resounding voices of the Global IR movement, ${ }^{11}$ has maintained that the ES, 'despite [its] biases and limitations, has offered concepts such as "international society," which ha[s] genuinely broader applicability beyond the UK or Europe and [is] used by scholars in other parts of the world'. ${ }^{12}$ Yongjin Zhang has also made a similar point when arguing that 'as Asian scholars take Western IR, and more particularly American IR, as the foil to drive their intellectual and theoretical innovation, the ES serves more than an inspiration by example for aspiring non-Western approaches to theorizing IR'. ${ }^{13}$ From an ES-insider perspective, we would like to add that the ES as a scholarship might not be the most obvious choice in terms of driving an academic career given both the prominence of 'American IR', or other scholarships, in mainstream IR journals and also the tension-field of conceptual discussions and critiques that the ES community is engaged in and confronted with.

The particularly favourable position of the ES with respect to contributing to Global IR scholarship is mostly due, as we shall see later, to its attentiveness to culture, norms, history, and social processes that inform IR and make up international relations in practice. Recent high-quality ES publications, such as 'The Globalization of International Society', ${ }^{14}$ 'Global International Society: A New Framework of Analysis', ${ }^{15}$ and 'The World Imagined', ${ }^{16}$ all feature 'the global' and 'diversity' as subjects of inquiry, and recent interventions in ES

\footnotetext{
Andrew Hurrell, "Beyond Critique: How to Study Global IR?," International Studies Review 18, no. 1 (2016): 150.

Melisa Deciancio, "International Relations from the South: A Regional Research Agenda for Global IR," International Studies Review 18, no. 1 (2016): 106-19.

9 Felix Anderl and Antonia Witt, "Problematising the Global in Global IR," Millennium, 49(1) (2020):11.

10 Acharya, "Global International Relations (IR) and Regional," 651.

11 For a recent and friendly critique of his agenda, see Anderl and Witt, "Problematising the Global in Global IR".

12 Acharya, "Global International Relations (IR) and Regional Worlds" 651, footnote 10.

13 Yongjin Zhang, "The Global Diffusion of the English School," in Guide to the English School of International Studies, ed. Cornelia Navari and Daniel Green (Chichester, West Sussex; Malden, MA: Wiley-Blackwell, 2014), 236.

14 Tim Dunne and Christian Reus-Smit, eds., The Globalization of International Society (Oxford, New York: Oxford University Press, 2017)

15 Barry Buzan and Laust Schouenborg, Global International Society: A New Framework for Analysis (Cambridge University Press, 2018).

16 Hendrik Spruyt, The World Imagined: Collective Beliefs and Political Order in the Sinocentric, Islamic and Southeast Asian International Societies, LSE International Studies (Cambridge: Cambridge University Press, 2020).
} 
debates have displayed a prominent disposition towards enlarging the scope of analysis of ES theory as well as its members' reflexivity and positionality. In addition, one may also note that, while much is yet to be done, some collaborations between exponents of the ES and proponents of the Global IR agenda have already fruitfully contributed to the debate and the work in progress of making the ES more aware and self-reflexive with its Eurocentric epistemological and theoretical foundations. This has happened both before and concomitantly with the current debate on the need for a Global IR. ${ }^{17}$

In light of these considerations, the present paper asks the following questions: How can the ES contribute to the Global IR agenda? What makes the ES suitable for this task, if at all, and what is still left to be done? To answer these questions, the paper will focus on the main tenets of the ES (first section) to then elaborate on what we call "areas for potential engagement" (second section) before moving to a series of proposals to narrow the gap between the Global IR agenda and the ES one (third section).

To be sure, the paper does not intend in any way to be prescriptive and deterministic in the sense of suggesting that the ES must engage with Global IR and that the claims made here are the only plausible ones. Rather, the arguments provided in these pages want to serve as a springboard for discussion to explore how the ES (again understood as a theory, as a body of research, and as a community of scholars) can contribute and add to constructing a more encompassing, just, and representative IR. Furthermore, as a last note before delving into the argument of the paper, our respective positionalities as authors should be contextualised, if briefly. In writing this paper, we are situating ourselves in the debate on the need for Global IR from the perspective of male, European (by birth and by intellectual upbringing), earlycareer scholars who consider themselves as part of the ES and who are currently actively taking part in the workings of the English School section at ISA. Our perspective, therefore, is that of two scholars fully embedded in the discipline with a particularly privileged angle on the inner working(s) of the ES both as a body of research and as a community of scholars. It is thus primarily this angle that informs the perspectives and the arguments presented in the paper.

\section{The Main Tenets of the English School Research Programme}

It would be very, perhaps far too ambitious to recap and condense all the main features and theoretical, analytical, and methodological components of the ES research programme in the space of a paper section, especially when entire collections and volumes have been devoted to each of these aspects. ${ }^{18}$ Yet, for the purpose of this section, we will make the effort to focus on those fundamental traits of the ES that distinguish it from other theories in IR, and especially on those that are susceptible to alignment with the Global IR agenda.

Perhaps the easiest way to start off is to resume the narrative where Acharya stopped,

17 Amitav Acharya and Barry Buzan, "Why Is There No Non-Western International Relations Theory? An Introduction," International Relations of the Asia-Pacific 7, no. 3 (2007): 287-312; Amitav Acharya and Barry Buzan, Non-Western International Relations Theory: Perspectives On and Beyond Asia (Taylor \& Francis, 2009); Amitav Acharya and Barry Buzan, "Why Is There No Non-Western International Relations Theory? Ten Years On," International Relations of the Asia-Pacific 17, no. 3 (2017): 341-70; Amitav Acharya and Barry Buzan, The Making of Global International Relations (Cambridge University Press, 2019).

18 Among others, see Andrew Linklater and Hidemi Suganami, The English School of International Relations: A Contemporary Reassessment, 1st ed. (Cambridge, UK ; New York: Cambridge University Press, 2006); Barry Buzan, An Introduction to the English School of International Relations: The Societal Approach, 1st ed. (Cambridge: Polity, 2014), 201; Cornelia Navari and Daniel Green, eds., Guide to the English School in International Studies, 1st ed. (Chichester, West Sussex ; Malden, MA: Wiley-Blackwell, 2014); Cornelia Navari and Tonny Brems Knudsen, eds., International Organizations in the Anarchical Society (Palgrave Macmillan, 
namely the concept of international society. In its hallmark definition, a society of states is 'a group of like-minded states' that 'conceive themselves to be bound by a common set of rules in their relations with one another and share in the working of common institutions'. ${ }^{19}$ Differently from an international system, which pertains to mechanic, anomic, and physical interactions, the concept of society involves a degree of 'sociability' that keeps actors together within a normative framework made of norms, rules, and institutions. The concept of international society has been reframed in recent years, with Dunne and Reus-Smit ${ }^{20}$ eliding the distinction between system and society and with Barry Buzan ${ }^{21}$ distinguishing between an inter-state society with a statist ontology and an inter-human society, which makes room for non-state actors, too. ${ }^{22}$ Yet, the main point to make here is that, as Acharya noted, the concept of international society has over the years found universal applicability, and not just in Europe. Especially since the 'regional agenda' of the ES took off in the late 2000s, ${ }^{23}$ international societies have been analysed, studied, and connected to the global, mostly Western-interpreted international society, thus showing the wide and functional applicability of the concept as maintained by Acharya himself.

The second main tenet of the ES is its attention and sensitivity to culture and history. The fundamental part that culture plays in international relations has always been a hallmark of ES theory since the times of the British Committee of IR, although it must be said that its conceptualisation and its role in the upholding of international order have changed over the decades. In the 'classical' ES, culture was seen and interpreted as a fundamental precondition for order, and cultural homogeneity was seen as a blueprint, an essential component for the formation of an international society. Such was the importance of cultural unity as the basis for international order (and such was the essentialism with which culture was treated!) that the process of decolonisation that took off after WW2 was framed as a possible 'revolt of the rest against the West' and as a destabilisation of international order tout-court. ${ }^{24}$

In more recent times, culture has found its autonomous place within the analytical framework of the ES, not necessarily as a basis for international society (which can be seen as capable of forming, developing, and surviving in a more pluralistic, functionalist logic) but as a potential element that informs Weltanschauungen, practices and interpretations of norms of specific (regional) international societies and world societies at the inter-human level. ${ }^{25}$

\footnotetext{
19 Hedley Bull, The Anarchical Society: A Study of Order in World Politics (Macmillan, 1977), 13.

20 Dunne and Reus-Smit, The Globalization of International Society.

21 Barry Buzan, From International to World Society?: English School Theory and the Social Structure of Globalisation (Cambridge University Press, 2004).

22 The notion of such an inter-human society has been termed world society but remains undertheorised. For a recent contributions and debate on the same see the special issue in International Politics, 55 no. 1, 2018.

${ }_{23}$ Barry Buzan and A. Gonzalez-Pelaez, eds., International Society and the Middle East: English School Theory at the Regional Level, 2009 ed. (Basingstoke; New York: Palgrave Macmillan, 2009); Laust Schouenborg, The Scandinavian International Society: Primary Institutions and Binding Forces, 1815-2010, 1st ed. (New York: Routledge, 2012); Linda Quayle, Southeast Asia and the English School of International Relations - A Region-Theory Dialogue (Palgrave Macmillan, 2013); Barry Buzan and Yongjin Zhang, eds., Contesting International Society in East Asia (Cambridge; New York: Cambridge University Press, 2014); Bettina Ahrens and Thomas Diez, "Solidarisation and Its Limits: The EU and the Transformation of International Society," Global Discourse 5, no. 3 (2015): 341-55; Jorge M. Lasmar, Danny Zahreddine, and Delber Andrade Gribel Lage, "Understanding Regional and Global Diffusion in International Law: The Case for a Non-Monolithic Approach to Institutions," Global Discourse 5, no. 3 (2015): 470-96; Yannis Stivachtis, "Interrogating Regional International Societies, Questioning the Global International Society," Global Discourse: An Interdisciplinary Journal of Current Affairs and Applied Contemporary Thought 5, no. 3 (2015): 327-340; Filippo Costa Buranelli, "Global International Society, Regional International Societies and Regional International Organizations: A Dataset of Primary Institutions," in International Organisations in the Anarchical Society (Palgrave Macmillan, 2019).

24 Mustapha Kemal Pasha, "Decolonizing the Anarchical Society," in Suganami, Carr and Humphreys, The Anarchical Society At 40, 92-110.

25 Spruyt, The World Imagined; Andrew Phillips and Christian Reus-Smit, Culture and Order in World Politics (Cambridge University Press, 2020).
} 
The attention to culture within the ES has also been revived within recent debates on the desirability of pluralism, ${ }^{26}$ as well as on syncretic and vanguardist approaches to culture and their impact on international order. ${ }^{27}$ With respect to differing interpretations of institutions for example, in the sense of solidarist or pluralist interpretations - the notion of polysemous institutions in, e.g., regional international societies, has been developed and employed in recent ES contributions, outlining an avenue for research focused on the discursive elements between practitioners of international relations. ${ }^{28}$

Furthermore, regarding history and its connection(s) to IR, one may say that the ES was born with it. Figures such as Herbert Butterfield, Donald Mackinnon, and Sir Michael Howard within the British Committee of IR were historians by training, and some of the classic works of ES thinkers were markedly history-based and devoted "to the "history of international society" as a means to understand and reconstruct international life in the past and the present' ${ }^{29}$ Moreover, also in recent times, history has informed many of the works within the ES. ${ }^{30}$ Yet, what is important to note is that the ES' view of history is based on the rejection of the Realist reading of history as recurrence and repetition, as well as of the teleological one of Liberalism. In the words of Dan Green, 'one of the great strengths of the English School (ES) has always been its expansive, sophisticated engagement with international relations history, which, unlike other IR approaches, is wedded to neither repetition (realism) nor teleology (liberalism, Marxism) '. ${ }^{31}$ As a matter of fact, in more precise terms, one may say that the ES approaches history in a more idiographic way ${ }^{32}$ and is rather marked by the waxing and waning of specific institutions of subsequent international orders (this last point is very well captured and efficiently rendered by the metaphor of the pendulum proposed by Adam Watson in his treatise on the evolution of international society). ${ }^{33}$ At the same time, the idiographic approach to history within the ES does not rule out a diachronic one, which in fact allows for the study of different orders across time. ${ }^{34}$

A third, fundamental component of the ES theoretical apparatus, inherently linked to the concepts of international society, culture, and history, is that of the world political system. This is 'the world-wide network of interaction that embraces not only states but also other

26 John Williams, Ethics, Diversity, and World Politics: Saving Pluralism From Itself? (Oxford, New York: Oxford University Press, 2015).

27 Barry Buzan, "Culture and International Society," International Affairs 86, no. 1 (2010): 1-25.

28 Bettina Ahrens and Thomas Diez, "Solidarisation and Its Limits: The EU and the Transformation of International Society," Global Discourse 5, no. 3 (2015): 341-55; Bettina Ahrens, "The European Union Between Solidarist Change and Pluralist ReEnactment," in International Organization in the Anarchical Society, ed. Tonny Brems Knudsen and Cornelia Navari (Palgrave Macmillan, 2019); Filippo Costa Buranelli, “'Do You Know What I Mean?' 'Not Exactly’: English School, Global International Society and the Polysemy of Institutions," Global Discourse 5, no. 3 (2015): 499-514; Kilian Spandler, Regional Organizations in International Society: ASEAN, the EU and the Politics of Normative Arguing (Springer International Publishing, 2018); Simon F. Taeuber, "Reconstructing the Silk Road: Norm Contestation in Sino-European Relations in Times of the Belt and Road Initiative," Rising Powers Quarterly 1, no. 1 (2020): 31-65.

${ }_{29}$ Brunelli Vigezzi, "The British Committee and International Society," in Navari and Green, Guide to the English School, 37.

30 Filippo Costa Buranelli, 'Knockin' on Heaven's Door: Russia, Central Asia and the Mediated Expansion of International Society," Millennium 42, no. 3 (2014): 817-36; Barry Buzan and George Lawson, The Global Transformation: History, Modernity and the Making of International Relations (Cambridge: Cambridge University Press, 2015); Manjeet S. Pardesi, "Mughal Hegemony and the Emergence of South Asia as a 'Region' for Regional Order-Building," European Journal of International Relations 25 no. 1 (2018): 276-301; Carsten-Andreas Schulz, "Territorial Sovereignty and the End of Inter-Cultural Diplomacy along the 'Southern Frontier'," European Journal of International Relations, 10 December 2018.

31 Daniel Green, "Improving upon 'Expansion': Metaphors to Shape the English School's International History," Cambridge Review of International Affairs 33, no. 4 (2020): 474.

32 Linklater and Suganami, The English School of International Relations.

33 Adam Watson, The Evolution of International Society: A Comparative Historical Analysis (Routledge, 1992).

34 Barry Buzan and Richard Little, International Systems in World History: Remaking the Study of International Relations 
political actors, both "above" and "below" it'. ${ }^{35}$ As a matter of fact, "the states system has always been part of a wider system of interaction in which groups other than states are related to each other, to foreign states and to international and supranational bodies, as well as to the states in which they are located'. ${ }^{36}$ This world political system refers, ultimately, to the ontology resulting from the sum of international system, international society, and world society - an environment in which states, individuals, and all sorts of NSAs participate and coexist. This is the 'holism' of the English School. This, again, seems to be the perfect entrypoint for Global IR research, but as we shall see, things are not that easy yet.

There are two additional points that we must elaborate on before moving on to the next section. The first one is the ES's methodology, which can be broadly understood as interpretivism. ${ }^{37}$ To be sure, when it comes to methodology, the ES is a broad church, within which several differentiations take place, especially when it comes to different degrees of mind-world dualism, mind-world monism, and different emphasis on either structure or agency ${ }^{38}$ with more recent contributions emphasising discourses, practices, or both.

The second and last tenet of the ES that we find relevant to the present discussion and objective of the paper is the geographical diversity of the ES in its analysis of different systems and societies - and this is inherently linked to the main tenet discussed in this section, that of international society and, more precisely, the regional turn thereof. While this was a feature of the first historical works, in particular Martin Wight's opus and the work of Adam Watson, it is in recent times with the inauguration of the 'regional agenda' that different world-views and regional orders have been brought to the fore, benefitting from theoretical and analytical rigour: not just Europe (which has been criticized for being seen as the matrix and blueprint of the expansion) ${ }^{39}$ but also Latin America, Eurasia and Central Asia, the Middle East, East Asia (with particular emphasis on South East Asia) and, to a lesser extent, Africa. This geographical diversity of analysis has been mirrored, although not to the same degree, by the increase in geographical diversity of scholars within the ES, which is now less confined to the UK and Europe with greater presence in other institutions, universities, and intellectual circles across the globe than it was the case before. ${ }^{40}$

To recap before moving on to the next section, within the Global IR incipient research programme, there have been arguments made about the ES being well-positioned to contribute to disenfranchising IR from its Western/Euro-centric foundations because of several characteristic marks of the theory - its encompassing understanding of 'international society', and in particular its regional application to elucidate non-Western worldviews; its

35 Bull, The Anarchical Society, 276.

36 Bull, The Anarchical Society, 278

37 Mark Bevir and Ian Hall, "Interpreting the English School: History, Science and Philosophy," Journal of International Political Theory 16, no. 2 (2020): 120-32; Mark Bevir and Ian Hall, "The English School and the Classical Approach: Between Modernism and Interpretivism,” Journal of International Political Theory 16, no. 2 (2020): 153-70. Bevir's and Hall's contributions are part of a whole special issue published in the Journal of International Political Theory (16, no.2, available at https://journals. sagepub.com/toc/ipt/16/2) entirely devoted to interpretivism and the ES.

38 Cornelia Navari, Theorising International Society - English School Methods (Palgrave Macmillan, London, 2009); Cornelia Navari, "Agents versus Structures in English School Theory: Is Co-Constitution the Answer?," Journal of International Political Theory 16, no. 2 (2020): 249-67; Peter Wilson, "The English School Meets the Chicago School: The Case for a Grounded Theory of International Institutions," International Studies Review 14, no. 4 (2012): 567-90; Charlotta Friedner Parrat, "On the Evolution of Primary Institutions of International Society," International Studies Quarterly 61, no. 3 (2017): 623-30; Spandler, Regional Organizations in International Society; Robert Falkner and Barry Buzan, "The Emergence of Environmental Stewardship as a Primary Institution of Global International Society," European Journal of International Relations 25, no. 1 (2019): 131-55; Filippo Costa Buranelli, “Authoritarianism as an Institution? The Case of Central Asia," International Studies Quarterly 64, no. 4 (2020): $1005-16$

39 Hedley Bull and Adam Watson, The Expansion of International Society (Clarendon Press, 1984).

40 Zhang, "The Global Diffusion of the English School". 
sensitivity to history, geography, and cultural diversity; its propensity for interpretivism; and its broad understanding of international politics, which is ultimately subsumed within the category of 'world political system'. So far, the synergy between the ES and Global IR indeed seems promising, waiting to be explored. What, then, is standing in-between? In order to understand why the ES has not yet taken Global IR fully into consideration, and to grasp the main obstacles to this process, we argue that one must look at the metatheoretical components of the ES, especially with respect to the concept of 'society', at its way of conducting interpretivist research, as well as at its conceptualisation of globality.

\section{The English School and Global IR - Possible Areas for Engagement, Contributions, and Synergy}

From the brief discussion offered above, it would seem that the ES is well-positioned to take on the challenges posed by a meaningful and genuine engagement with making IR more global. Geographical diversity, theoretical and methodological holism, historical sensitivity, and an attention that is evenly distributed to agency and structure all have the merit of placing the ES at the heart of the process of creating a truly Global IR. Yet, one may argue that there are still areas in need of development and engagement to make the ES fully receptive to the Global IR emancipatory goals. We will begin by reviewing the issues already discussed by some prominent scholars in the most recent ES literature ${ }^{41}$ and then move on to the areas in need of improvement that we believe are present within the ES corpus and that have not been yet paid sufficient heed. Importantly, the four points that follow are interconnected, and are divided only for analytical purposes. The same goes for the way in which we suggest improving on them in the next section.

The first major obstacle to a more encompassing synergy between the ES and Global IR is a thorough, systematic, and fine-grained understanding of the origins of 'global international society' rooted in colonialism, inequality of people, violent conquest, and suppression. What Mustapha Kemal Pasha calls a 'decolonisation' of the anarchical society to tackle the 'spectrality' of colonialism is very much needed to understand not just the main ontology that lies at the heart of the ES research programme, that of international society, but also of the ES as a community. ${ }^{42}$ As has been recently argued,

perhaps due to an inferiority complex in relation to American IR, the ES seems unwilling or
unable to see its own position of privilege. British IR, even with its own set of problems, is
well-funded, well-respected and influential. It is also at home-ground language-wise, and it
has been able to put up a fight against American dominance in the discipline. In light of all
this, the ES must start to question its self-image as underdog. Rather, it plays an active part
in shaping the discipline, and consequently needs more reflexivity in its approach to gate-
keeping and the image it reproduces of itself and of its central concepts. ${ }^{43}$

The story of the globalization of international society, although now being more finegrained and more receptive of non-Western experiences and contributions, is still very much leaning towards the category of 'order' as opposed to that of 'justice'. This brings us to our second point.

\footnotetext{
${ }^{41}$ Hidemi Suganami, Madeline Carr, and Adam Humphreys, eds., The Anarchical Society at 40: Contemporary Challenges and Prospects (Oxford, New York: Oxford University Press, 2017); Charlotta Friedner Parrat, Kilian Spandler, and Joanne Yao, "The English School as a Theory and a Scholarly Community," Cambridge Review of International Affairs 33, no. 4 (2020): 483-86.

42 Pasha, "Decolonizing the Anarchical Society".

43 Parrat, Spandler, and Yao, "The English School as a Theory and a Scholarly Community," 484. Importantly, the contribution by Friedner-Parrat, Spandler, and Yao is part of a broader discussion forum hosted by the Cambridge Review of International Affairs, 3 no. 4 (available at https://www.tandfonline.com/toc/ccam20/33/4?nav=tocList) in which recent and future trends of and within the 
The second critique, which has been powerfully voiced again by Charlotta FriednerParrat, Kilian Spandler, and Joanne Yao, pertains to the narrative provided by ES classical scholars on the 'expansion' story. According to the three theorists,

\begin{abstract}
although many studies on this topic take peripheral actors into account, they usually appear as passive or at best reactive, and as seeking to 'accede' to international society rather than actively shaping it. The ES account has thus minimized non-European agency, as well as the dynamic and constitutive nature of interactions between European and non-European agents in international history. ${ }^{44}$
\end{abstract}

This point has been acknowledged also by Daniel Green, who has aptly argued that 'the English School's weakness with history has instead been Eurocentrism, epitomized in its narrative of the development in early modern Europe of the norms and practices of contemporary international society and their subsequent "expansion" out to the rest of the world through colonization and cultural imperialism'. ${ }^{45}$ This criticism focuses on a reading of history that is mostly from Europe, by Europe, for Europe, and relies on a reading of historical processes that are somehow unilinear, deterministic, and qualitatively neutral - all features encapsulated by the term 'expansion'. Interestingly, or perhaps tellingly, Hedley Bull himself in the preparatory writings for The Anarchical Society said that 'we are not accustomed to looking to international relations from the perspective from which most of the world sees it, the perspective from the underdog', ${ }^{46}$

While the recent work edited by Tim Dunne and Chris Reus-Smit has done a great job in opening up new avenues for inquiry, especially on the 'construction of the global' as a historical product and as an analytical category, much work still needs to be done, especially to understand and reflect on other experiences and views of 'the global' ${ }^{47}$ For example, while we argue that there are not necessarily so many English things about the ES, the lack of detailed historical accounts of the British colonisation of India and on the Commonwealth is somehow puzzling.- especially for a theory and a research programme that originated in Britain in the 1950s and has always paid attention to the history of colonisation and the dynamics of imperialism over time.

As these two interrelated critiques are already present in the available literature, in the remainder of this section we venture into expanding on four additional blind spots within the ES that can potentially be addressed to build more solid bridges between the school and the Global IR project.

The first one is, partly contra Acharya, the meaning of society itself and its usage within ES theorisation, which hinges on a specific genealogy. As may be recalled from above, Amitav Acharya identified in the concept of international society the main overlap between the ES and Global IR, on the basis that the ES "has offered concepts such as "international society," which ha[s] genuinely broader applicability beyond the UK or Europe and [is] used by scholars in other parts of the world'. ${ }^{48}$ Yet, as recent scholarship has noted, ${ }^{49}$ this concept

44 Parrat, Spandler, and Yao, "The English School as a Theory and a Scholarly Community," 484.

45 Green, "Improving upon 'Expansion'," 474.

46 Quoted in Vigezzi, "The British Committee and International Society," 49.

${ }^{47}$ Andrew Hurrell, "Cultural Diversity within Global International Society," in Culture and Order in World Politics, ed. Andrew Phillips and Christian Reus-Smit, LSE International Studies (Cambridge: Cambridge University Press, 2020), 115-36; Spruyt, The World Imagined.

48 Acharya, "Global International Relations (IR) and Regional Worlds," 651, footnote 10.

49 Jens Bartelson, "Towards a Genealogy of "Society" in International Relations," Review of International Studies 41 , no. 4 (2015): 675-92; Pasha, "Decolonizing the Anarchical Society". 
of 'society' is very much indebted to Western sociology and political philosophy imbued with elements of Christianity, natural law, morality (societas), and rational individualism (mirrored in the pluralist idea of international society). Moreover, this way of understanding 'society' is also linked to an understanding of sovereignty as propriety (mirrored in Hedley Bull's treatise of the fundamental rules of international order with respect to the 'stability of possession'), again developed on the backdrop of specific intellectual, political, and societal challenges of modernity in the peculiarity of the European context. Within the intellectual genesis of the ES, 'European international society, or states system, had taken shape against a specifically political background. Butterfield points out that it is a historically "unique" phenomenon'. ${ }^{50}$ While for Wight 'to belong to international society, in the early modern period, was to belong to European Christendom', Butterfield 'drew attention to the idea of international society embodied in the Gottingen historians' conceptions of "the European States-System"". ${ }^{51}$ The result is, as Jens Bartelson has noted in a critique that has perhaps not been paid the necessary heed, that

\begin{abstract}
the concept of society [within the ES] carries a distinctive semantic baggage that reflects a series of intellectual commitments once made in response to problems of political and scientific legitimacy perceived to be pressing at the threshold of European modernity. As a consequence of being a point of condensation of all these concerns, there are reasons to doubt that the concept of society will be of much help when trying to make sense of the past and present of international political life outside its context of emergence. ${ }^{52}$
\end{abstract}

Mustapha Pasha has echoed this critique by arguing that 'the West can no longer authorize imperial arrangements, but it can still carry the expectation that only its version of sociability can triumph worldwide despite decolonization' ${ }^{53}$ As will be evident later, this pertains to what has been called the emic and etic approaches to international society ${ }^{54}$ in a welcome and still relatively unexplored move to leverage on the anthropological insights within the ES that, as aptly noted by recent contributions, are there but are seldom acknowledged or incorporated into wider theorising. ${ }^{55}$

Another area that the ES ought to explore more in order to further contribute to the Global IR agenda is the theorisation of the state within international society. It is only recently that the ES has started to take seriously the fact that the postcolonial world has entered global international society (see above) featuring an incredibly variegated array of statehoods and statenesses ${ }^{56}$ This is, perhaps, one of the strongest and deepest legacies of the 'system' ontology within the ES tripartition, linked mostly to segmentation, sameness, security, and mechanic interactions relating to the logics of security dilemma and balance of power in a realist fashion. This perspective, as has been noted, 'places into context historically produced structural impediments to functionality and state effectiveness. Attention to these impediments also affords better appreciation of the impossibility of disentangling 'inside'

50 Vigezzi, "The British Committee and International Society," 42.

51 Vigezzi, "The British Committee and International Society," 41.

52 Bartelson, "Towards a Genealogy of "Society" in International Relations," 689.

53 Pasha, "Decolonizing the Anarchical Society," 202-3, emphasis added.

54 Nicholas Lees, "International Society Is to International System as World Society Is to ...? Systemic and Societal Processes in English School Theory," Journal of International Relations and Development 19, no. 3 (2016): $285-311$.

55 Wilson, "The English School Meets the Chicago School”; Nicolás Terradas, "The Quest for Order in Anarchical Societies: Anthropological Investigations," International Studies Review 22, no. 1 (2020): 98-121.

56 Kilian Spandler, "Regional Standards of Membership and Enlargement in the EU and ASEAN," Asia Europe Journal 16, no. 2 (2018): 183-98; Robert Yates, "The English School and Postcolonial State Agency: Social Roles and Order Management in Southeast Asia and the Asia-Pacific," International Theory (2020): 1-29. 
from 'outside', the 'domestic' from the 'international'. Post-colonial state capacity lies at the interstices of both'. ${ }^{57}$ As discussed later, this is linked to the issue of 'globality'.

The third area for engagement we would like to emphasise pertains to language and analytical categories. Here, the problem lies in the tension identifiable within the ES between idiography and nomothesis, between the particular and the general, between the contingent and the structural. This, the astute reader will notice, is inherently linked to Bartelson's critique of 'society' as a prism and as an explanans. Already, Martin Wight, in his work on diplomatic investigations and historical state systems, ${ }^{58}$ wondered whether to include the relations between city-states in ancient Greece under the institution of balance of power, for while on the one hand their interactions clearly resembled a balance-of-power pattern, he was, on the other hand, concerned that the category of 'balance of power' would have made little sense to an ancient Greek. Without categorising it as such, Wight was grappling with the issue of transferability of concepts and with what in interpretivist methodological research is known as the migration of context and the principle of charity ${ }^{59}$ This is especially true for that wing of the ES that is now commonly known for being 'soft positivist', or, as it has been called elsewhere, 'analyticist', and based on mind-world dualism. ${ }^{60}$

The fourth and last area for engagement through which the ES can enhance dialogue with and contribute to Global IR would be to critically examine the meaning of 'the global' within ES parlance. Scholars such as Tim Dunne, Chris Reus-Smit, and Barry Buzan (alone and in collaboration with both Amitav Acharya and Laust Schouenborg) have spent a considerable amount of time and words in towards reframing and problematizing 'the global', both from an international and a world society perspective. Before this, a conception of the global as the result of the European expansion of international society was understood as the result of the entry of non-Western polities within the structure of rules, norms, and institutions created by and for Europeans. As Bull maintained,

\begin{abstract}
the non-European or non-Western majority of states in the world today, which played little role in shaping the foundations of the international society to which they now belong, have sought naturally and properly to modify it so that it will reflect their own special interests. It should not be overlooked, however, that by seeking a place in this society they have given their consent to its basic rules and institutions. ${ }^{61}$
\end{abstract}

Now, the understanding is different. Dunne, Reus-Smit and collaborators, with a nod to global sociology, speak of 'globalisation' as opposed to 'expansion', taking into account qualitative changes that greatly informed the series of transformations underlying that very process, such as those pertaining to the moral purposes of states and sovereignty, as well as exogenous global forces that affected these very transformations, such as the rise of global capitalism. ${ }^{62}$ For them, 'globality' was a matter of 'globalizing' as much as 'becoming' ${ }^{63}$ For Buzan and Schouenborg, 'global international society' is a problematic term in itself, and one

57 Pasha, "Decolonizing the Anarchical Society," 93. 1977).

58 Martin Wight, Systems of States (Leicester University Press [for] the London School of Economics and Political Science,

59 Donald Davidson, Inquiries into Truth and Interpretation (Oxford University Press, 2001).

60 Patrick Thaddeus Jackson, The Conduct of Inquiry in International Relations: Philosophy of Science and Its Implications for the Study of World Politics (Routledge, 2010); Filippo Costa Buranelli, "The English School and Regional International Societies: Theoretical and Methodological Reflections," in Regions in International Society (Brno Czech Republic: MUNI Press, 2014); Costa Buranelli, "Do You Know What I Mean?".

61 Quoted in Dunne and Reus-Smit, The Globalization of International Society, 26.

62 Buzan and Lawson, The Global Transformation.

63 Dunne and Reus-Smit, The Globalization of International Society, 29. 
that needs further theorization. Their volume on the matter is an impressive systematization and fine-grained account of four ideal-type models to illustrate the composition and structure of global international society: like-units, regional/sub-global, hierarchy/privilege, and functional differentiation. ${ }^{64}$ With respect to the origins of global international society, they focus on 'monocentric' and 'polycentric' models, but it is the first one that takes precedence in the book. ${ }^{65}$ Buzan has also pioneered ground-breaking work on 'globality' and world society, pointing at several weaknesses and inconsistencies of such analytical categorisation and offering a theorization of 'transnational' and 'inter-human' world societies, seeking to explore the political and advocacy aspects of them. What one may consider an approach for further theorisation and development to meet Global IR is to look at this diversity more closely and from different parts of the world, but more on this below.

\title{
4. A Tentative Research Agenda
}

Taking into account the issues and different areas for engagement within the ES identified above, how can the theory and, indeed, the community of scholars who are associated with it address them (or at least problematise them with active self-reflection) and contribute to a more global IR? The starting point for advancing these suggestions is to keep in mind that, as a necessary and fundamental step in realising the aspirations of Global IR, what matters is not only 'who does the theorising?' but also 'what they say' and what theories, epistemologies, and categories of analysis they follow.

With respect to decolonising the narrative of the expansion of international society, now called globalisation, it is fundamental that the voices, imaginaries, worldviews, and experiences of the Southern polities that came into contact with European actors (empires, but also missionaries, traders, and commercial companies) are recovered, contextualised, and put in relation with Europe in a logic of co-constitution. As Pinar Bilgin has aptly noted,

\begin{abstract}
the proponents of creating a "non-Western IR theory" often rely on Eurocentric narratives on world history while failing to see the ways in which peoples and states of the global South have been the "constitutive outside". "Constitutive outside" refers to the ideas and experiences of those people and states in the global South who have shaped the global North even as the latter are not always aware of and/or acknowledge what they owe the latter. ${ }^{66}$
\end{abstract}

Archival work and sustained engagement with constitutive outsiders, such as the Mapuche in Latin America, ${ }^{67}$ will benefit ES historical research by revealing alternative conceptualisations of order, of 'globality', and of sociability, and would make possible answering the question that, somehow paradoxically and presciently, was posed by Herbert Butterfield already in 1959: 'What would our feelings have been if we were been born Arabians or Indians?'. ${ }^{68}$ Which leads us to the second point about the category of 'society' itself.

As noted above, the main criticism advanced to the category of international society that is seemingly applicable to the rest of the world is that, at a deep level, it consists of metatheoretical assumptions defined by the political, social, and scientific experience

64 Buzan and Schouenborg, Global International Society, Chapter 1.

65 Buzan and Schouenborg, Global International Society, 41.

66 Pinar Bilgin, "How to Globalise IR?," E-IR, 2018, https://www.e-ir.info/2018/04/22/how-to-globalise-ir/.

67 Carsten-Andreas Schulz, "Territorial Sovereignty and the End of Inter-Cultural Diplomacy along the 'Southern Frontier'," European Journal of International Relations 25, no. 3 (2019): 878-903.

68 Quoted in Vigezzi, "The British Committee and International Society," 42. 
of (early) modernity in Europe. In this respect, one way to move forward towards more participation of the ES within Global IR would be to consider the category of society as an explanandum itself, and not anymore as an explanans, i.e., delving into the question of why specific forms of formal and informal relations develop and become institutionalised differently in different parts of the world. The ES would sharpen its understanding of society by looking at how different forms of relational ontologies, sociability, and interaction were and are possible, examining which values and norms inform these, and reflecting on interhuman communication and behaviour. Kinship, for example, is a fundamental category of association that is seldom, if ever, discussed in ES circles. ${ }^{69}$ This would be in line with what has been advocated by Bartelson, in particular the adoption of the term 'forms of human association', not only 'to allow for more historical and cultural variety, but also in order to draw attention to the fact that well before the emergence of the modern concept of society, the default understanding was that such forms are boundless and heterogeneous rather than bounded and homogeneous'. ${ }^{70}$

This would also have importance for making the ES more global, especially with respect to its 'regional agenda'. As a matter of fact, while Bartelson makes the case for using 'forms of human association' mostly from a historical perspective, seeking to recover 'conceptions of human association from other parts of the world, and explore their role in the shaping of modern international relations before they were marginalised and forgotten' ${ }^{71}$ one may argue that such an approach would also be useful to interrogate the many historical and current regional worlds and worldviews. Hence, the focus would be on what Latour describes as 'the tracing of new associations and the designing of their assemblages', with 'accounting for how society is held together'. ${ }^{72}$

This also comes to the fore in our respective work on Central Asia and Latin America. In Central Asia, for example, 'sosedstvo' (Cyrillic 'соседство'; English 'the neighbourhood') is a term frequently used to describe IR in the region, a term that emphasises the role of border communities and inter-human ties there despite the violence of supra-imposed borders during the Soviet times. Telling is that across the region, a very popular proverb is 'a good neighbour is better than a distant relative'. Timur Dadabayev, in his work on decolonising IR in Central Asia, has also highlighted the concept of 'neighbourhood', and investigates the norms and practices associated with it. ${ }^{73}$ In Latin America, the term 'comunidad' (English 'community') is one widely used by practitioners when speaking of the region and relations between neighbours, rather than system or society, and the emphasis in narratives is on a shared history of suffering under colonial and hegemonic regimes, as well as both intra-state and political violence. Yet 'none of this should be taken to imply that the classics of modern social theory are irrelevant to our concerns. Rather the opposite. But instead of uncritically applying their conceptions of society trans-historically and transculturally, we may instead reformulate their questions so as to gain a better understanding of a world that is ours' ${ }^{74}$ And

\footnotetext{
69 Joseph Chinyong Liow, "The Kinship Factor in International Relations: Kinship, Identity Construction, and Nation Formation in Indonesia-Malaysia Relations" (PhD thesis, London School of Economics and Political Science, 2003).

70 Bartelson, "Towards a Genealogy of 'Society' in International Relations," 689.

71 Bartelson, “Towards a Genealogy of 'Society’ in International Relations," 690.

72 Quoted in Dunne and Reus-Smit, The Globalization of International Society, 34.

73 Timur Dadabaev, "Decolonizing Central Asian International Relations: Central Asia in Post-Colonial Age," (Presented at the Cambridge Central Asia Forum in collaboration with the Centre of Development Studies and GCRF COMPASS Project, 27 November 2020), https://centralasia.group.cam.ac.uk/events/DadabaevTalk; Filippo Costa Buranelli, "Central Asian Regionalism or Central Asian Order? Some Reflections," Central Asian Affairs 8, no. 1 (2021): 1-26.

74 Bartelson, "Towards a Genealogy of 'Society' in International Relations,"692.
} 
this takes us to the third point.

If one of the main goals of globalising IR is the inclusion of the experience, the perspective, the meaning(s) and the worldviews of peoples and collectivities from the South, then one may argue that a methodology very much rooted in 'being on the ground' and in the proximity of the unfolding of the 'social life' one intends to investigate may be apt to serve for the task at hand. A thorough discussion and critique of the New Institutionalist turn within the ES was conducted by Wilson, and the proposed pathway then was precisely the above. In this respect, the good news is that the ES would not have to reinvent the wheel, as grounded approaches have been around for quite a while. ${ }^{75}$ As Cornelia Navari has noted, ${ }^{76}$ the interpretivism that very much informs ES research can be found in participant observation, the study of memoirs, biographies, recollections, diaries and journals, and even in ethnographies and grounded theory approaches as recently advocated. ${ }^{77}$ For the outlined purpose, we side with Wilson in that a constructivist grounded theory approach specifically, in the sense proposed by Kathy Charmaz $^{78}$ rather than earlier, ontologically and epistemologically differing versions, ${ }^{79}$ would aid the globalising effort regarding IR. Such an approach would combine the interpretation of the context investigated with a strong empiricism resulting from engagement with the primary sources used for the investigation and research. ${ }^{80}$ In other words, the starting point for such an inquiry would be the perspectives and experiences of practitioners of and within international relations, rather than IR or ES concepts and jargon on the matter.

Research conducted in this way would ideally be supported by a desire to learn local languages, capture the subtleness of local metaphors used to depict social life, read the local literature, grasp the way in which local epics, myths, symbols, and stories have informed a particular way of life, understand the local political theory, the indigenous cosmology (understood in its etymological sense of 'study of order'), and views of 'the good life'. It would entail becoming acquainted with the formal and informal logics that inform specific orders in the world, with the rituals and the meanings that would give content to such order and lead to an appreciation and comprehension for diversity and differentiation. Such an approach would not necessarily dispense with indicators and 'marks' of sociability but would have the advantage of more groundedly (pun intended) capturing the essence of a given social condition from the perspective of those embedded in it. ${ }^{81}$

This also has potential implications for the agency-structure debate within the ES itself. As a matter of fact, this methodological 'situatedness' would very much shift the ES on the agency side as opposed to a more structuralist approach to order. And yet, this would be in line with both a classical understanding of the ES and the goal of Global IR to elevate the agency and the contribution of non-Western actors to a level playfield. As argued by Navari,

75 Wilson, "The English School Meets the Chicago School".

76 Cornelia Navari, "English School Methodology," in Navari and Green, Guide to the English School, 205-21.

77 Wilson, "The English School Meets the Chicago School"; Terradas, "The Quest for Order in Anarchical Societies".

Kathy C. Charmaz, Constructing Grounded Theory: A Practical Guide through Qualitative Analysis, 1st ed. (London; Thousand Oaks, Calif: SAGE Publications Ltd, 2006).

79 Barney G. Glaser and Anselm L. Strauss, The Discovery of Grounded Theory: Strategies for Qualitative Research (Aldine de Gruyter, 1967); Barney G. Glaser, Theoretical Sensitivity: Advances in the Methodology of Grounded Theory (Sociology Press, 1978).

80 Mats Alvesson and Kaj Sköldberg, Reflexive Methodology: New Vistas for Qualitative Research, ${ }^{\text {st }}$ ed. (London; Thousand Oaks, Calif: SAGE Publications Ltd, 2000).

${ }_{81}$ As an example, Simon F. Taeuber at the University of St Andrews is currently carrying out grounded research into conceptions of (regional) orders and normative fabrics in Latin America in the context of the Belt and Road Initiative and contemporary SinoLatin American relations. 
actor-centred methods [...] are of relevance [to the ES] since consciously directed action is an important explanandum in ES theory. [And s]ince ES theories focus mainly on social man, the social context becomes important in understanding social action. This demands theorizing context, as well as the relationship of action to context' ${ }^{82}$

As the reader may infer, this would facilitate more interdisciplinary dialogue between IR scholars and area studies specialists towards researching globally meaningful and locally informed narratives about social orders and interactions between political communities. As Andrew Hurrell has recently argued, 'Area and Regional Studies are not about the exotic and the esoteric; as with Global History, they are simply about how we can do better social science' ${ }^{83}$ The crucial aspect to do so, methodologically speaking, is to emphasise what above has been called the migration of context and the principle of charity. In other words, making sure the account we provide as researchers is as close as possible to the meaning held by the actors within the context we are studying while at the same time making it intelligible to those outside it.

The last suggestion offered is to resume a critical theorisation of 'the global' within ES research, elaborating on the work of Buzan and Schouenborg and advancing this with respect to both relations between political communities in history (that is, relations between secondorder societies) and the world society take. With respect to the former, one may argue that there is plenty of exciting work to do regarding the 'polycentric' model of the origination of global international society. Encounters between civilisations and different worldviews, where negotiations of meanings and practices revolving around different institutions collide and clash, are a fascinating and fertile site to study the syncretic approach to how the global has been formed over centuries 'on the basis of cultural diversity and fusion'. ${ }^{84}$ This strand of research would in fact continue the excellent initial work done by some scholars within the ES. ${ }^{85}$

If Hedley Bull argued that non-Western societies 'have given their consent to [European international society's] basic rules and institutions', then a good avenue for research would be to uncover whether this was actually consent; if yes, how this was explicated; if not, how it was resisted; and overall, how these critical sites of encounter, contestation, and clashing Weltanschauungen morphed into a new sociability. With respect to world society, Matt Weinert has convincingly argued that a task for future research would be the investigation of different world societies, since '[many] globalities exist (e.g., the world economy, international sport, religion, culture, and technology). Each possesses distinctive, enduring logics, behaviours, institutions, and normative commitments to coordinate and structure-activity, solve problems, and generate and refine common interests and identities. Even if such a research agenda fragments the holism of the world society concept, it nevertheless gains by its treatment as a historical and empirical reality - that is, as encapsulating discrete logics, knowledges, normative commitments, and practices that evidence the multitude of ways we are citizens

82 Navari, "English School Methodology," 212-3.

83 Hurrell, "Beyond Critique," 151.

84 Buzan and Schouenborg, Global International Society: A New Framework for Analysis, 40.

85 Shogo Suzuki, Yongjin Zhang, and Joel Quirk, eds., International Orders in the Early Modern World: Before the Rise of the West, 1st ed. (Milton Park, Abingdon, Oxon ; New York: Routledge, 2013); John Anthony Pella, Africa and the Expansion of International Society: Surrendering the Savannah, $1^{\text {st }}$ ed. (London ; New York, NY: Routledge, 2014); Andrew Phillips and J. C. Sharman, International Order in Diversity: War, Trade and Rule in the Indian Ocean (Cambridge: Cambridge University Press, 2015). 
not merely of, but in, the world'. ${ }^{86}$ This would not only remind us that 'the global' is always contested, negotiated, and co-constituted by different actors and meanings, but also that there are multiple, variegated 'globals' rooted in a polyphony of contributions, experiences, and histories that make up the Bullian 'world political system'.

\section{Conclusions}

It is undeniable that Global IR, in all its facets, is marking a turning point in the discipline and the profession of IR. In this paper, we have argued that the ES has a lot of potential to contribute to this important and desirable agenda, and we have highlighted the ways in which this can happen as well as the motivations as to why this should happen. We hope we have convincingly shown how and under what conditions, despite its limitations and despite frequent calls for its underexploited character, the ES may well prove to be an ally, and indeed a seminal contributor, to the entrenchment and development of Global IR. This is in line with recent developments within the ES, especially with respect to fostering dialogue and mutual learning with scholars from the Global South, with paying attention to institutional and normative dynamics in the postcolonial world, and with embracing multiplicity and interdisciplinarity in a rigorous fashion. ${ }^{87}$ However, this paper cannot do justice to all the possible ways in which the ES and Global IR can work in synergy and mutually reinforce each other. Far more research and intellectual work lies ahead. That the trend is that of moving from 'international' to 'global' society seems to be a correct assessment (Buzan forthcoming) ${ }^{88}$ Yet, exactly how the global is studied and told is a future topic for ES scholars to theorise, analyse, and understand.

\section{Bibliography}

Acharya, Amitav. "Global International Relations (IR) and Regional Worlds: A New Agenda for International Studies.” International Studies Quarterly 58, no. 4 (2014): 647-59.

Acharya, Amitav, and Barry Buzan. Non-Western International Relations Theory: Perspectives On and Beyond Asia. Taylor \& Francis, 2009.

. The Making of Global International Relations. Cambridge University Press, 2019.

- "Why Is There No Non-Western International Relations Theory? An Introduction." International Relations of the Asia-Pacific 7, no. 3 (2007): 287-312.

_. "Why Is There No Non-Western International Relations Theory? Ten Years On." International Relations of the Asia-Pacific 17, no. 3 (2017): 341-70.

Ahrens, Bettina. "The European Union Between Solidarist Change and Pluralist Re-Enactment." In International Organization in the Anarchical Society, edited by Tonny Brems Knudsen and Cornelia Navari. Palgrave Macmillan, 2019.

Ahrens, Bettina, and Thomas Diez. "Solidarisation and Its Limits: The EU and the Transformation of International Society." Global Discourse 5, no. 3 (2015): 341-55.

Alvesson, Mats, and Kaj Sköldberg. Reflexive Methodology: New Vistas for Qualitative Research. First. London: Thousand Oaks, Calif: SAGE Publications Ltd, 2000.

Anderl, Felix, and Antonia Witt. "Problematising the Global in Global IR." Millennium 49, no. 1 (2020): 32-57.

Bartelson, Jens. "Towards a Genealogy of 'Society' in International Relations." Review of International Studies 41, no. 4 (2015): 675-92.

${ }^{86}$ Matthew S. Weinert, "World Society and the Globality of IR," Cambridge Review of International Affairs 33, no. 4 (2020): 480-82.

87 Filippo Costa Buranelli, "Is the English School Still an Underexploited Resource? And Whither the English School? An Introduction," Cambridge Review of International Affairs 33, no. 4 (2020): 464-66; Green, "Improving upon "Expansion"; Raymond Hinnebusch, "The English School and the Periphery Regions: The Case of MENA and the Road Ahead," Cambridge Review of International Affairs 33, no. 4 (2020): 487-90. 
Bevir, Mark, and Ian Hall. "Interpreting the English School: History, Science and Philosophy." Journal of International Political Theory 16, no. 2 (2020): 120-32.

—. "The English School and the Classical Approach: Between Modernism and Interpretivism." Journal of International Political Theory 16, no. 2 (2020): 153-70.

Bilgin, Pinar. How to Globalise IR? E-IR, 2018. https://www.e-ir.info/2018/04/22/how-to-globalise-ir/.

Bull, Hedley. The Anarchical Society: A Study of Order in World Politics. Macmillan, 1977.

Bull, Hedley, and Adam Watson. The Expansion of International Society. Clarendon Press, 1984.

Buzan, Barry. An Introduction to the English School of International Relations: The Societal Approach. 1st ed. Cambridge: Polity, 2014.

. "Culture and International Society." International Affairs 86, no. 1 (2010): 1-25. https://doi.org/10.1111/ j.1468-2346.2010.00866.x.

- From International to World Society?: English School Theory and the Social Structure of Globalisation. Cambridge University Press, 2004.

Buzan, Barry. Forthcoming. "Global Society: A Structural Account of Humankind Since the Ice Age," n.d.

Buzan, Barry, and Ana Gonzalez-Pelaez, eds. International Society and the Middle East: English School Theory at the Regional Level. 2009th ed. Basingstoke ; New York: Palgrave Macmillan, 2009.

Buzan, Barry, and George Lawson. The Global Transformation: History, Modernity and the Making of International Relations. Cambridge: Cambridge University Press, 2015.

Buzan, Barry, and Laust Schouenborg. Global International Society: A New Framework for Analysis. Cambridge University Press, 2018.

Buzan, Barry, and Richard Little. International Systems In World History: Remaking the Study of International Relations. Oxford: New York: Oxford University Press, 2000.

Buzan, Barry, and Yongjin Zhang, eds. Contesting International Society in East Asia. Cambridge: New York: Cambridge University Press, 2014.

Chakrabarty, Dipesh. Provincializing Europe. Princeton University Press, 2007.

Charmaz, Kathy C. Constructing Grounded Theory: A Practical Guide through Qualitative Analysis. 1st ed. London; Thousand Oaks, Calif: SAGE Publications Ltd, 2006.

Costa Buranelli, Filippo. "Authoritarianism as an Institution? The Case of Central Asia." International Studies Quarterly 64, no. 4 (2020): 1005-16.

_. "Central Asian Regionalism or Central Asian Order? Some Reflections." Central Asian Affairs 8, no. 1 (2021): 1-26.

—. “'Do You Know What I Mean?' 'Not Exactly': English School, Global International Society and the Polysemy of Institutions.” Global Discourse 5, no. 3 (2015): 499-514.

_ . "The English School and Regional International Societies: Theoretical and Methodological Reflections." In Regions in International Society. Brno Czech Republic: MUNI Press, 2014.

_ _ "Global International Society, Regional International Societies and Regional International Organizations: A Dataset of Primary Institutions.” In International Organisations in the Anarchical Society. Palgrave Macmillan, 2019.

- "Is the English School Still an Underexploited Resource? And Whither the English School? An Introduction." Cambridge Review of International Affairs 33, no. 4 (2020): 464-66.

_. "Knockin' on Heaven's Door: Russia, Central Asia and the Mediated Expansion of International Society." Millennium 42, no. 3 (2014): 817-36.

Dadabaev, Timur. "Decolonizing Central Asian International Relations: Central Asia in Post-Colonial Age." In Cambridge Central Asia Forum in Collaboration with the Centre of Development Studies and GCRF COMPASS Project, 2020. https://centralasia.group.cam.ac.uk/events/DadabaevTalk.

Davidson, Donald. Inquiries into Truth and Interpretation. Inquiries into Truth and Interpretation. Oxford University Press, 2001.

Deciancio, Melisa. "International Relations from the South: A Regional Research Agenda for Global IR." International Studies Review 18, no. 1 (2016): 106-19.

Dunne, Tim, and Christian Reus-Smit, eds. The Globalization of International Society. Oxford, New York: Oxford University Press, 2017.

Falkner, Robert, and Barry Buzan. "The Emergence of Environmental Stewardship as a Primary Institution of Global International Society.” European Journal of International Relations 25, no. 1 (2019): 131-55. 
Glaser, Barney G. Theoretical Sensitivity: Advances in the Methodology of Grounded Theory. Sociology Press, 1978.

Glaser, Barney G., and Anselm L. Strauss. The Discovery of Grounded Theory: Strategies for Qualitative Research. Aldine de Gruyter, 1967.

Green, Daniel. "Improving upon 'Expansion': Metaphors to Shape the English School's International History." Cambridge Review of International Affairs 33, no. 4 (2020): 474-76.

Hinnebusch, Raymond. "The English School and the Periphery Regions: The Case of MENA and the Road Ahead." Cambridge Review of International Affairs 33, no. 4 (2020): 487-90.

Hurrell, Andrew. "Beyond Critique: How to Study Global IR?" International Studies Review 18, no. 1 (2016): $149-51$.

. "Cultural Diversity within Global International Society." In Culture and Order in World Politics, edited by Andrew Phillips and Christian Reus-Smit. Cambridge: Cambridge University Press, 2020.

Jackson, Patrick Thaddeus. The Conduct of Inquiry in International Relations: Philosophy of Science and Its Implications for the Study of World Politics. Routledge, 2010.

Lasmar, Jorge M., Danny Zahreddine, and Delber Andrade Gribel Lage. "Understanding Regional and Global Diffusion in International Law: The Case for a Non-Monolithic Approach to Institutions." Global Discourse 5, no. 3 (2015): 470-96.

Lees, Nicholas. "International Society Is to International System as World Society Is to ...? Systemic and Societal Processes in English School Theory." Journal of International Relations and Development 19, no. 3 (2016): 285-311.

Linklater, Andrew, and Hidemi Suganami. The English School of International Relations: A Contemporary Reassessment. 1st ed. Cambridge, UK ; New York: Cambridge University Press, 2006.

Liow, Joseph Chinyong. The Kinship Factor in International Relations: Kinship, Identity Construction, and Nation Formation in Indonesia-Malaysia Relations. London School of Economics and Political Science, 2003.

Navari, Cornelia. “Agents versus Structures in English School Theory: Is Co-Constitution the Answer?” Journal of International Political Theory 16, no. 2 (2020): 249-67.

- Theorising International Society - English School Methods. London: Palgrave Macmillan, 2009.

Navari, Cornelia, and Daniel Green, eds. Guide to the English School in International Studies. 1st ed. Chichester, West Sussex ; Malden, MA: Wiley-Blackwell, 2014.

Navari, Cornelia, and Tonny Brems Knudsen, eds. International Organizations in the Anarchical Society. London: Palgrave Macmillan, 2019.

Pardesi, Manjeet S. "Mughal Hegemony and the Emergence of South Asia as a 'Region' for Regional OrderBuilding.” European Journal of International Relations 25, no. 1 (2018): 276-301.

Parrat, Charlotta Friedner, Kilian Spandler, and Joanne Yao. "The English School as a Theory and a Scholarly Community." Cambridge Review of International Affairs 33, no. 4 (2020): 483-86.

Parrat, Friedner and Charlotta. "On the Evolution of Primary Institutions of International Society." International Studies Quarterly 61, no. 3 (2017): 623-30.

Pasha, Mustapha Kemal. "Decolonizing the Anarchical Society." In Suganami, Carr and Humphreys. The Anarchical Society At 40, 92-110.

Pella, John Anthony. Africa and the Expansion of International Society: Surrendering the Savannah. New York, NY: Routledge, 2014.

Phillips, Andrew, and Christian Reus-Smit. Culture and Order in World Politics. Cambridge University Press, 2020.

Phillips, Andrew, and J.C. Sharman. International Order in Diversity: War, Trade and Rule in the Indian Ocean. Cambridge: Cambridge University Press, 2015.

Quayle, Linda. Southeast Asia and the English School of International Relations - A Region-Theory Dialogue. Palgrave Macmillan, 2013.

Schouenborg, Laust. The Scandinavian International Society: Primary Institutions and Binding Forces, 1815-2010. 1st ed. New York: Routledge, 2012.

Schulz, Carsten-Andreas. "Territorial Sovereignty and the End of Inter-Cultural Diplomacy along the 'Southern Frontier'." European Journal of International Relations 25, no. 3 (2019): 878-903.

Sharma, Ananya. "Decolonizing International Relations: Confronting Erasures through Indigenous Knowledge Systems.” International Studies 58, no. 1 (2021): 25-40.

Spandler, Kilian. Regional Organizations in International Society: ASEAN, the EU and the Politics of Normative 
Arguing. Springer International Publishing, 2018.

"Regional Standards of Membership and Enlargement in the EU and ASEAN." Asia Europe Journal 16, no. 2 (2018): 183-98.

Spruyt, Hendrik. "The World Imagined: Collective Beliefs and Political Order in the Sinocentric, Islamic and Southeast Asian International Societies." In LSE International Studies. Cambridge: Cambridge University Press, 2020.

Stivachtis, Yannis, ed. "Interrogating Regional International Societies, Questioning the Global International Society." Global Discourse: An Interdisciplinary Journal of Current Affairs and Applied Contemporary Thought 5, no. 3 (2015).

Suganami, Hidemi, Madeline Carr, and Adam Humphreys, eds. The Anarchical Society at 40: Contemporary Challenges and Prospects. Oxford, New York: Oxford University Press, 2017.

Suzuki, Shogo, Yongjin Zhang, and Joel Quirk, eds. International Orders in the Early Modern World: Before the Rise of the West. 1st ed. Milton Park, Abingdon, Oxon ; New York: Routledge, 2013.

Taeuber, Simon F. "Reconstructing the Silk Road: Norm Contestation in Sino-European Relations in Times of the Belt and Road Initiative." Journal of Rising Powers and Global Governance 1, no. 1 (2020): 31-65.

Terradas, Nicolás. "The Quest for Order in Anarchical Societies: Anthropological Investigations." International Studies Review 22, no. 1 (2020): 98-121.

Tucker, Karen. "Unraveling Coloniality in International Relations: Knowledge, Relationality, and Strategies for Engagement." International Political Sociology 12, no. 3 (2018): 215-32.

Tully, James. Strange Multiplicity: Constitutionalism in an Age of Diversity. The Seeley Lectures. Cambridge: Cambridge University Press, 1995.

Vigezzi, Brunelli. "The British Committee and International Society."In Navari and Green, Guide to the English School, 37-58.

Watson, Adam. The Evolution of International Society: A Comparative Historical Analysis. Routledge, 1992.

Weinert, Matthew S. "World Society and the Globality of IR." Cambridge Review of International Affairs 33, no. 4 (2020): 480-82.

Wight, Martin. Systems of States. Leicester University Press [for] the London School of Economics and Political Science, 1977.

Williams, John. Ethics, Diversity, and World Politics: Saving Pluralism From Itself? Oxford, New York: Oxford University Press, 2015.

Wilson, Peter. "The English School Meets the Chicago School: The Case for a Grounded Theory of International Institutions.” International Studies Review 14, no. 4 (2012): 567-90.

Yates, Robert. The English School and Postcolonial State Agency: Social Roles and Order Management in Southeast Asia and the Asia-Pacific. International Theory, 2020.

Zhang, Yongjin. "The Global Diffusion of the English School." In Navari and Green, Guide to the English School, 223-40. 